\title{
Zinc Electrodeposition from Chloride Solutions onto Glassy Carbon Electrode
}

\author{
Luis Humberto Mendoza-Huízar, ${ }^{1, *}$ Clara Hilda Rios-Reyes, ${ }^{1}$ and María Guadalupe Gómez-Villegas ${ }^{1}$
}

Universidad Autónoma del Estado de Hidalgo. Centro de Investigaciones Químicas, Mineral de la Reforma, Hidalgo.

C.P. 42184, México. hhuizar@uaeh.edu.mx. Telephone: +52 (771) 717-2000 ext. 2203.

Received August 10, 2009; accepted January 28, 2010

\begin{abstract}
An electrochemical study of zinc deposition was carried out in baths containing $0.5 \mathrm{M} \mathrm{ZnCl}_{2}$ and $0.4 \mathrm{M} \mathrm{H}_{3} \mathrm{BO}_{3}$. From the voltammetric study it was found that, in our experimental conditions, zinc electrodeposition is quasi-reversible and occurs under charge transfer control. The average coefficient diffusion calculated was $D=$ $7.14 \times 10^{-6} \mathrm{~cm}^{2} \mathrm{~s}^{-1}$ while the standard constant at electrode charge was $8.78 \times 10^{-3} \mathrm{cms}^{-1}$. The nucleation and growth parameters determined from the potentiostatic study showed that, at bigger overpotentials, a vertical growth is favored, suggesting a dendritic growth. The critical cluster's size calculated was 2 , indicating that each active site is formed by two zinc atoms on the glassy carbon electrode (GCE) surface, while the $\Delta \mathrm{G}$ for the formation of stable nucleus was 1.35 $\times 10^{-20} \mathrm{~J} /$ nuclei. The Scanning Electron Microscopy images showed thin platelets of hexagonal crystals and dendrites at lower and higher overpotentials applied, respectively.
\end{abstract}

Key words: Zinc, Quasi-reversible, Charge transfer control, Kinetic study, Nucleation.

\section{Introduction}

Coatings of zinc and its alloys are of great practical importance because of their capacity to protect ferrous substrates against corrosion [1-4]. Several factors such as zinc concentration [5], complexing agents [6], anions [7,8], and additives [9] play fundamental roles in zinc electrodeposition. These factors may modify the texture and morphology of zinc electrodeposited coatings [10-13]. Although, several works have been reported in literature, the relation between the morphology of the deposits and their electrochemical parameters are still not clear [14]. Thus, those works that attempt to get an insight into the nucleation and crystal growth process are few [14-18].

Zinc electrodeposition from acid baths has been commercially practiced for a long-time, mainly from acid chloride and sulfate baths $[14,18]$. However, despite its great significance to the plating industry, the nucleation and crystal growth process is often not well understood. Thus, for example, the $\mathrm{Zn}^{2+}$ ions can interact with $\mathrm{SO}_{4}^{2-}$ or $\mathrm{Cl}^{-}$ions forming metal-ion complexes whose stability constants are $10^{2.38}$ and $10^{0.96}$ at $25^{\circ} \mathrm{C}$, respectively. Therefore, a strong interaction of $\mathrm{Zn}^{2+}$ ions with anions results in larger overpotentials [19]. Although, the zinc electrodeposition is well recognized, the kinetic parameters related to this are unclear yet. Some reports in the literature indicate that the zinc electrodeposition is fast and autocatalytic controlled by an electronic transfer charge [18, $20,21]$, other reports suggest a diffusion control [14, 22, 23]. However, only few works report the nucleation parameters
Resumen. Se realizó un estudio electroquímico del proceso de deposito de zinc a partir de baños que contienen $0.5 \mathrm{M} \mathrm{ZnCl}_{2}$ y $0.4 \mathrm{M}$ $\mathrm{H}_{3} \mathrm{BO}_{3}$. Del estudio voltamperométrico se encontró que, en nuestras condiciones experimentales, la electrodepositación del zinc es cuasi reversible y ocurre bajo un control por transferencia de carga. El coeficiente de difusión calculado fue $D=7.14 \times 10^{-6} \mathrm{~cm}^{2} \mathrm{~s}^{-1}$ mientras que la constante de velocidad estándar del electrodo fue $8.78 \times 10^{-3}$ $\mathrm{cms}^{-1}$. Los parámetros de nucleación y crecimiento obtenidos a partir del estudio potenciostático; mostraron que a grandes sobrepotenciales la velocidad de crecimiento perpendicular se favorece, sugiriendo un crecimiento dendrítico. El tamaño crítico de núcleo calculado fue de 2 , indicando que cada sitio activo está formado por dos átomos de zinc en la superficie del electrodo de carbón vítreo (GCE). La $\Delta \mathrm{G}$ requerida para formar un núcleo estable fue de $1.35 \times 10^{-20} \mathrm{~J} /$ núcleo. Las imágenes obtenidas por medio de microscopia electrónica de barrido mostraron cristales hexagonales planos y dendritas a bajos y altos sobrepotenciales, respectivamente.

Palabras claves: Zinc, cuasi-reversible, transferencia de carga, cinética, nucleación.

associated with zinc electrodeposition, especially on carbon substrates [18, 22, 24]. The main advantage, of use glassy carbon electrode (GCE) in the electrodeposition studies, is that it is an inert substrate, and it is possible to study nucleation and growth neglecting the metal-metal interaction. Thus, in this paper, the zinc electrodeposition onto GCE from acid chloride baths is examined using cyclic voltammetry, chronoamperometry and scanning electron microscopy, in order to get a better understanding of the zinc electrodeposition process from acid chloride baths.

\section{Results}

\section{Voltammetric study}

Figure 1 shows a typical cyclic voltammogram, at the scan rate of $5 \mathrm{mVs}^{-1}$, corresponding to zinc deposition onto GCE from a solution containing $0.5 \mathrm{M} \mathrm{ZnCl}_{2}$ and $0.4 \mathrm{M} \mathrm{H}_{3} \mathrm{BO}_{3}$. It is possible to note, at direct scan, a peak A at $-1.098 \mathrm{~V}$. During the inverse of the potential scan, it is possible to note two crossovers, $E_{\mathrm{C}}$ and $E_{\mathrm{CEP}}$. The crossover $E_{\mathrm{C}}(-1.090 \mathrm{~V})$ is typical of the formation of a new phase involving a nucleation process. Also, last potential is associated with an electrocatalytic point [25]. The second crossover potential $E_{\mathrm{CEP}}$ was recorded at $-1.02 \mathrm{~V}$ and may be related to the conditional equilibrium potential of couple $\mathrm{Zn}^{2+} / \mathrm{Zn}^{0}$. In the anodic zone, it was possible to observe a principal peak B at around $-0.918 \mathrm{~V}$. The 


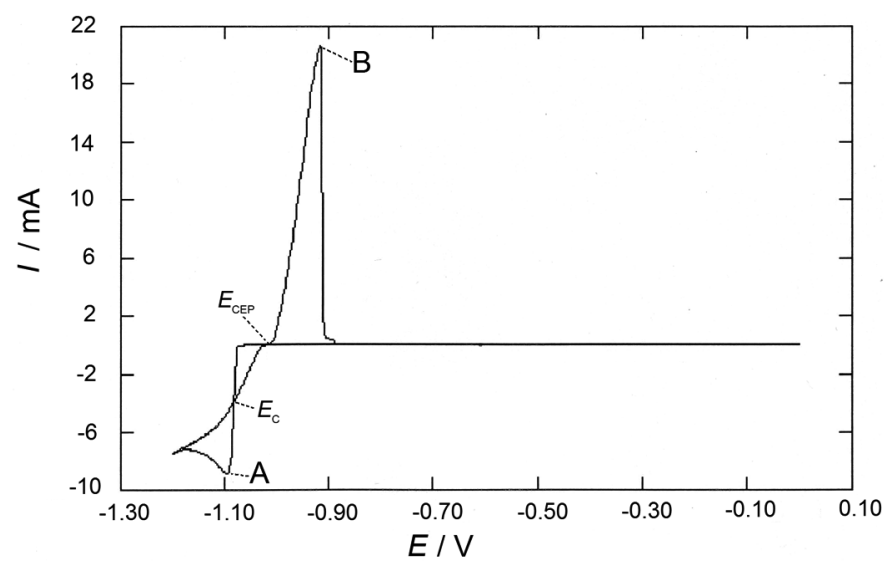

Fig. 1. A typical cyclic voltammogram obtained from the GCE/ $0.5 \mathrm{M}$ $\mathrm{ZnCl}_{2}$ and $0.4 \mathrm{M} \mathrm{H}_{3} \mathrm{BO}_{3}(\mathrm{pH} 4.5)$ system. The potential scan rate was started at $0 \mathrm{~V}$ toward the negative direction with a potential scan rate of $5 \mathrm{mV} \mathrm{s}^{-1}$.

existence of this peak suggests the presence of zinc electrodeposited during the direct scan.

To determine the limiting control of the zinc electrodeposition, the current value associated with peak A was plotted as a function of $v^{1 / 2}(v=$ scan rate), see Fig. 2, according to the Berzins-Delahay's equation [26, 27]. A non-linear relationship was found. Last result may be indicative either the presence of other contributions to the overall current during the $\mathrm{Zn}$ deposition process additional to the $3 \mathrm{D}$ nucleation contribution or the existence of quasi reversible system [28]. However, in the voltammetric curves it was not possible to observe the presence of a cathodic current caused by the proton reduction process overlapped with the current of zinc electrodeposition. In order to verify this behavior we compared the cathodic charge with the anodic charge at different scan rates. The results are summarized in Table 1. Note that the ratio $\left(Q_{\mathrm{c}}=Q_{\mathrm{a}}\right.$. ) remains approximately constant at unity indicating that the current recorded during the cathodic and anodic scan is due to the zinc

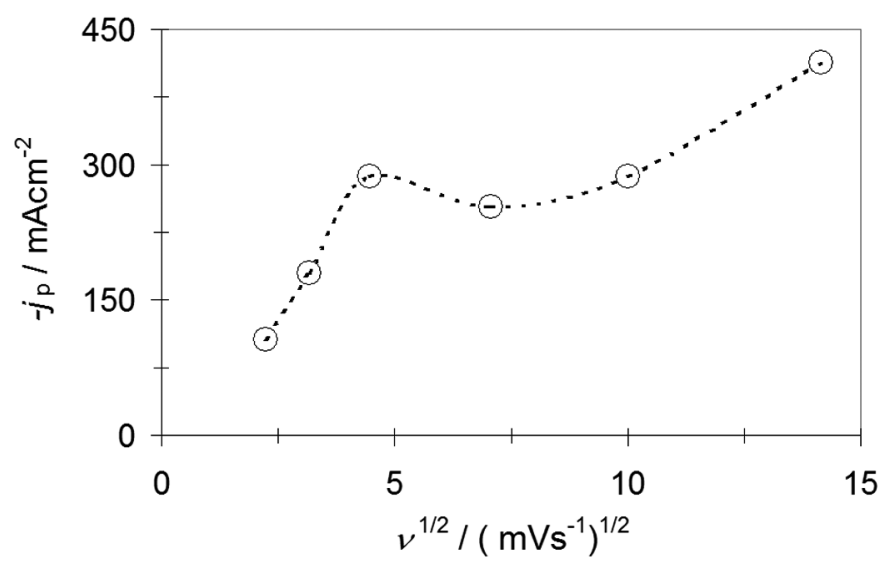

Fig. 2. Plot of the experimental cathodic current density peak $\left(j_{\mathrm{p}}\right)$ as a function of scan rate $\left(v^{1 / 2}\right)$ for Peak A. The broken line corresponds to the tendency of the experimental data.
Table 1. Potential dependence of physical parameters derived from the voltammetric study during $\mathrm{Zn}$ electrodeposition onto a GCE electrode from an aqueous solution containing $0.5 \mathrm{M}$ of $\mathrm{ZnCl}_{2}$ and $0.4 \mathrm{M}$ $\mathrm{H}_{3} \mathrm{BO}_{3}$ at $\mathrm{pH} 4.5$.

\begin{tabular}{ccccccc}
\hline $\begin{array}{c}\mathrm{v} / \\
\mathrm{mVs}^{-1}\end{array}$ & $\mathrm{I}_{\mathrm{B}} / \mathrm{I}_{\mathrm{A}}$ & $\begin{array}{c}\left(\mathrm{E}_{\mathrm{B}}-\mathrm{E}_{\mathrm{A}}\right) \\
/ \mathrm{V}\end{array}$ & $\begin{array}{c}\mathrm{E}_{1 / 2} \\
/ \mathrm{V}\end{array}$ & $\begin{array}{c}\mathrm{Q}_{\mathrm{c}} \\
/ \mathrm{Ccm}^{-2}\end{array}$ & $\begin{array}{c}\mathrm{Q}_{\mathrm{a}} \\
\mathrm{Ccm}^{-2}\end{array}$ & $\mathrm{Q}_{\mathrm{c}} / \mathrm{Q}_{\mathrm{a}}$ \\
\hline 5 & 2.34 & 0.180 & -1.04 & 4.95 & 4.46 & 1.11 \\
10 & 1.84 & 0.210 & -1.05 & 2.40 & 2.28 & 1.05 \\
20 & 1.71 & 0.290 & -1.06 & 2.00 & 2.10 & 0.95 \\
50 & 1.47 & 0.324 & -1.06 & 0.85 & 0.92 & 0.92 \\
100 & 1.16 & 0.334 & -1.07 & 0.42 & 0.41 & 1.02 \\
200 & 1.18 & 0.320 & -1.07 & 0.20 & 0.22 & 0.91 \\
\hline
\end{tabular}

electrodeposition. The analysis of the ratio $\left(I_{\mathrm{B}} / I_{\mathrm{A}}\right)$ in function of the scan rate showed a deviation from the unit, while the values of $\left(E \mathrm{p}_{\mathrm{B}}-E \mathrm{p}_{\mathrm{A}}\right)$ were increased with the scan rate. Note that the values of $E_{1 / 2}$ remains without depending on the scan rate. These features are typical of a quasi reversible system. Also, It has been reported that for these kind of systems the peak current is given by [28]:

$$
i=n F A C_{0} D^{1 / 2}\left(\frac{n F}{R T}\right)^{1 / 2} \psi(E) v^{1 / 2}
$$

Where $\Psi(E)$ depends on the potential. Thus, from equation (1), the average coefficient diffusion calculated was $D=7.14 \times$ $10^{-6} \mathrm{~cm}^{2} \mathrm{~s}^{-1}$. Matsuda and Ayabe have proposed a reversibility factor (L) for electrode reactions [28, 29] given by:

$$
\Lambda=\frac{k^{0}}{\left[D_{O}^{1-\alpha} D_{R}^{\alpha}\left(\frac{n F}{R T}\right) v\right]^{1 / 2}}
$$

Where $k^{0}$ is the standard constant at electrode $\left(\mathrm{cms}^{-1}\right), D_{R}$ is the diffusion coefficient of reduced species, $D_{O}$ is the diffusion coefficient of oxided species, $n$ the number of electrons transferred, $F$ is the Faraday's constant, $v$ is the scan rate, $\Lambda$ is a kinetic parameter related to $\left(E \mathrm{p}_{\mathrm{B}}-E \mathrm{p}_{\mathrm{A}}\right)$ [28]. Matsuda and Ayabe reported that for a reversible system: $\mathrm{L}>15$, quasireversible system: $15>\Lambda>10^{-2(1+\alpha)}$ and irreversible system: $\Lambda<10^{-2(1+\alpha)}$. Assuming that $D_{R}$ is equivalent to $D_{O}$ the equation (2) can be written as $\Lambda=k^{0} /(78 D v)^{0.5}=42.37 k^{0} v^{-0.5}$. Additionally, in our experimental conditions $\alpha$ was calculated as 0.5 , therefore the relationship $132.48(D v)^{0.5}>k^{0}>$ $0.009(D v)^{0.5}$ can be derived for the quasi reversible case. From equation (2) and the the value of $\Lambda=0.095$ obtained from $\left(E \mathrm{p}_{\mathrm{B}}-E \mathrm{p}_{\mathrm{A}}\right)$ the average standard constant at electrode charge calculated was $8.78 \times 10^{-3} \mathrm{cms}^{-1}$. Last value is compatible with the range of $7.9 \times 10^{-1} \mathrm{cms}^{-1}>k^{0}>5.4 \times 10^{-5} \mathrm{cms}^{-1}$ at $v$ $=5-200 \mathrm{mVs}^{-1}$. On the other hand, this value compares favorably with the obtained by Matsuda and Ayabe for the zinc 
electrodeposition from alkaline solutions [29]. Here, it must be remembered that the Matsuda and Ayabe criteria considers that the charge-transfer rate constant and the sweep rate are related. Thus, the transfer coefficient affects the symmetry of the curve. In the case where $\alpha<0.5$, the cathodic peak is more rounded than the anodic peak, where the resultant broadening decreases the peak height. Moreover, the current-potential curve shifts to the potential axis. Thus, it has been reported that the range in where the Matsuda and Ayabe's equation may be applied is located at $0.3<\alpha<0.7$ [30].

\section{Chronoamperometric study}

Detailed information about the electrocrystallization process can be obtained from potentiostatic deposition. Figure 3 shows a set of current transients recorded at different potentials from $\mathrm{GCE} / 0.5 \mathrm{M} \mathrm{ZnCl}_{2}$ and $0.4 \mathrm{M} \mathrm{H}_{3} \mathrm{BO}_{3}$ system. In these transients it is clear the presence of an induction time, which depends of the potential applied. After this initial induction time an increase in the current, due to the 3D nucleation and growth, was recorded. From the voltammetric study, it was evidenced a charge transfer control during the deposition process of zinc under our experimental conditions. Abyaneh et al [31] have proposed for transients controlled by charge transfer the equation (3).

$$
i_{3 D}=P_{1}\left\{1-\exp \left[-P_{2}\left(\left(t-P_{3}\right)^{2}-\frac{2\left(t-P_{3}\right)}{P_{4}}+\frac{2}{P_{4}}-\frac{2}{P_{4}} \exp \left(-P_{4}\left(t-P_{3}\right)\right)\right)\right]\right\}
$$

where

$$
P_{1}=F a\left[z k_{3}^{\prime}+z_{H}\left(k_{3 H}^{\prime}+k_{3 H} \frac{k_{3}^{\prime}}{k_{3}}-k_{2 H}^{\prime}\right)\right]
$$

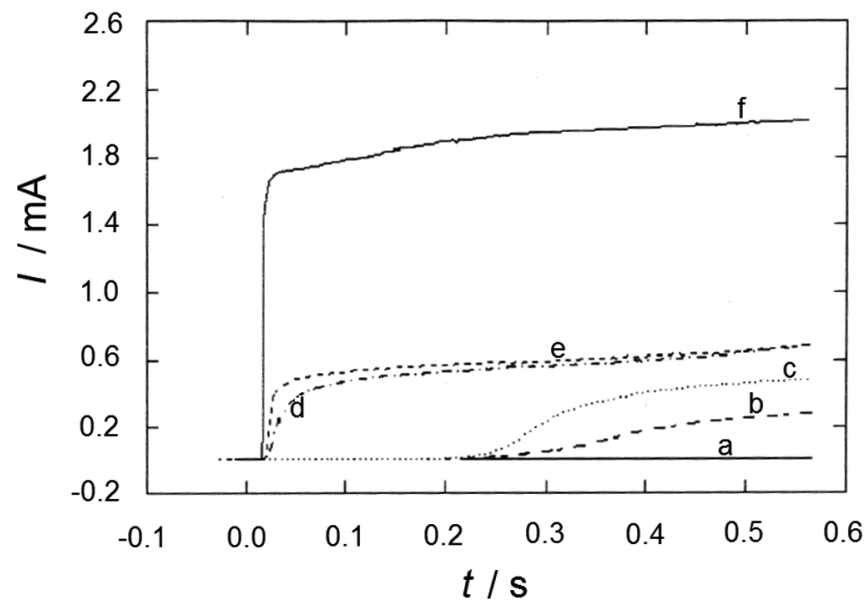

Fig. 3. A set of transients obtained from the GCE/ $0.5 \mathrm{M} \mathrm{ZnCl}_{2}$ and $0.4 \mathrm{M} \mathrm{H}_{3} \mathrm{BO}_{3}(\mathrm{pH} 4.5)$ system by the single potential step technique for different potential step values a) -1.045 b) -1.050 c) -1.055 d) 1.060 e) -1.065 and f) $-1.080 \mathrm{~V}$

$$
\begin{gathered}
P_{2}=\frac{\pi M^{2} k_{3}^{2} A_{3}}{A_{3}^{\prime} \rho^{2}} \\
P_{3}=\tau \\
P_{4}=A_{3}
\end{gathered}
$$

$A_{3}$ is a constant related to the nucleation rate conversion of an active site to a nuclei (nuclei $\mathrm{cm}^{-2} \mathrm{~s}^{-1}$ ), $A_{3}=$ nucleation rate constant $\left(\mathrm{s}^{-1}\right), k_{3}=$ growth rate constant in the parallel direction to the substrate (moles $\mathrm{cm}^{-2} \mathrm{~s}^{-1}$ ), $k_{3}^{\prime}=$ growth rate constant in the vertical direction to the substrate $\left(\right.$ moles $\left.\mathrm{cm}^{-2} \mathrm{~s}^{-1}\right), \tau$ is the induction time, $a$ is the substrate area, $k_{2 H}^{\prime}$ is associated with the proton reduction in two dimensions and $k_{3 H}$ and $k_{3 H}^{\prime}$ corresponds to the proton reduction on the deposit in parallel and perpendicular direction respectively. From the voltammetric study it was shown that, in the potential range studied the zinc electrodeposition, is carried out without the influence of the proton reduction. Thus, the equation (3) can be simplified as

$i_{3 D}=z a F k_{3}\left\{1-\exp \left[-P_{2}\left(\left(t-P_{3}\right)^{2}-\frac{2\left(t-P_{3}\right)}{P_{4}}+\frac{2}{P_{4}}-\frac{2}{P_{4}} \exp \left(-P_{4}\left(t-P_{3}\right)\right)\right)\right]\right\}$

Fig. 4 shows a comparison of two experimental current transients recorded at -1.065 and $-1.085 \mathrm{~V}$ with those theoretically generated by non-linear fitting of experimental data to Eq. (8). It could be observed, that the model expressed by eq. (8) adequately accounted for the experimental behavior of the transients. The physical parameters calculated from the adjustments of Eq. (3) are summarized in Table 2. It was seen that an increment of the nucleation rate was obtained when the potential applied was decreased. Also, note the growth rate constants $k_{3}$ and the combined constant $k_{3}^{2} A_{3}$ increase and diminish respectively when the applied potential decreases. Last results suggest that at lower overpotentials a growth in parallel direc-

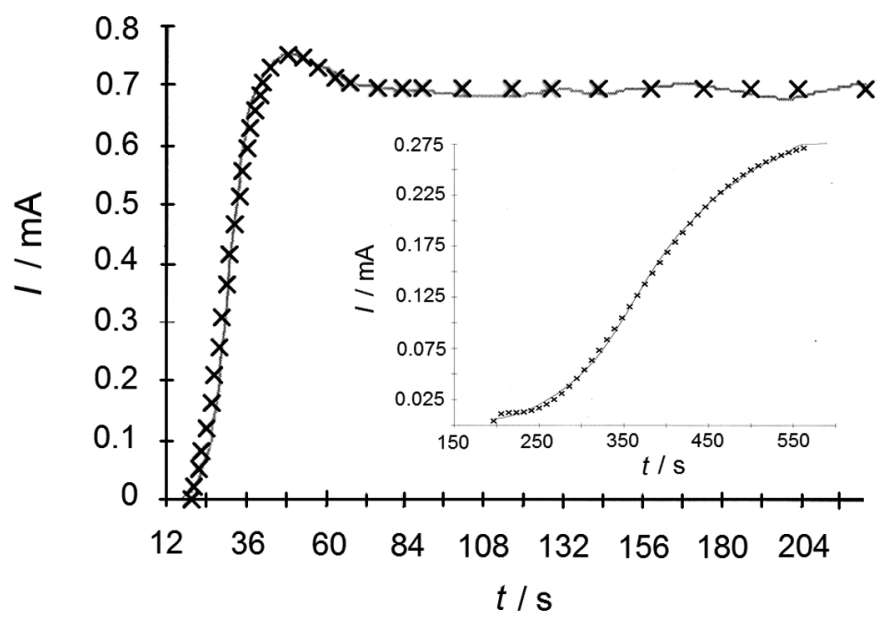

Fig. 4. Comparison between an experimental ( $)$ and a theoretical transient ( $\mathrm{x} \times \mathrm{x})$ when the potential value of a) -1.070 and $b$ ) $-1.050 \mathrm{~V}$ were considered. 
tion of the substrate is favored while at bigger overpotentials a vertical growth might be expected.

\section{Analysis of the kinetic parameters.}

From the nucleation rate values reported (Table 2), it is possible to calculate the Gibbs free energy of nucleation employing the next equation (equation (2.42) in reference [32]):

$$
\Delta G=-\frac{k_{B} T}{\eta^{2}} \frac{d \ln \left(M_{3 d}^{d a}\right)}{d \eta^{-2}}=-\frac{k_{B} T}{\eta^{2}} \frac{d\left(\ln \left[A_{3}^{\prime} \exp \left(\frac{\alpha z e \eta}{k_{B} T}\right)\right]\right)}{d \eta^{-2}}
$$

where $\Delta G$ is the Gibbs free energy of nucleation, $\mathrm{J} /$ nuclei; $k_{B}$ is the Boltzmann constant $\left(1.38066 \times 10^{-23} \mathrm{~J} \mathrm{~mol}^{-1}\right), T$ is the absolute temperature, $\mathrm{K}, \eta$ is the overpotential, $z$ is the charge transferred during the zinc reduction process and $e$ is the elementary charge of the electron. On the other hand, the critical nuclei can be calculated employing (equation (2.43) in reference [32]):

$$
n_{c}=-\frac{2 k_{B} T}{z e \eta^{3}} \frac{d\left(\ln \left[A_{3}^{\prime} \exp \left(\frac{\alpha z e \eta}{k_{B} T}\right)\right]\right)}{d \eta^{-2}}
$$

It is important to mention that equations (9) and (10) are valid in the case of a direct attachment mechanism. The plot $\ln \left(M_{3 d}^{d a}\right)$ vs $\eta^{-2}$ showed a linear tendency with a $\mathrm{d}\left(\ln \left(M_{3 d}^{d a}\right)\right.$ )$/ \mathrm{d} \eta=4.3 \times 10^{-3}$. Thus, the $\Delta \mathrm{G}$ calculated for this system was $1.35 \times 10^{-20} \mathrm{~J} /$ nuclei. This energy corresponds to the $\Delta \mathrm{G}$ value requirements for the formation of stable nucleus, the average critical cluster's size $\left(n_{c}\right)$ calculated employing eq (10) was $n_{c}=2$ suggesting that each active site is formed by two zinc atoms on the GCE surface.

Table 2. Potential dependence for the nucleation parameters during $\mathrm{Zn}$ electrodeposition onto a GCE electrode from aqueous solution containing $0.5 \mathrm{M}$ of $\mathrm{ZnCl}_{2}$ and $0.4 \mathrm{M} \mathrm{H}_{3} \mathrm{BO}_{3}$ at $\mathrm{pH} 4.5$. The values were obtained from best-fit parameters of the experimental $j$ - $t$ plots by using Eq. (8).

\begin{tabular}{cccc}
\hline $\mathrm{E} / \mathrm{V}$ & $\begin{array}{c}k_{3}^{\prime} \times 10^{5} \\
/ \mathrm{mol} \mathrm{s}^{-1}\end{array}$ & $\begin{array}{c}k_{3}^{2} A_{3} \times 10^{6} \\
/ \mathrm{mol} \mathrm{cm}^{-4} \mathrm{~s}^{-1}\end{array}$ & $\begin{array}{c}A_{3} \\
/ \mathrm{s}^{-1}\end{array}$ \\
\hline-1.045 & 1.734 & 4.845 & 0.054 \\
-1.050 & 2.015 & 1.755 & 0.150 \\
-1.055 & 3.008 & 1.460 & 0.330 \\
-1.060 & 2.721 & 0.266 & 0.991 \\
-1.065 & 3.495 & 0.359 & 1.735 \\
-1.070 & 3.162 & 0.330 & 2.669 \\
-1.080 & 3.675 & 0.270 & 3.761 \\
\hline
\end{tabular}

\section{Morphological analysis}

The morphology of the electrodeposits was studied by Scanning Electron Microscopy. Figure 5a shows the morphology of the deposit obtained at $-1.045 \mathrm{~V}$. Observe that the coatings consisted of thin platelets of hexagonal crystals, which were stacked on each other. Figure $5 b$ shows the deposit obtained at $-1.065 \mathrm{~V}$, in this image it may be observed a perpendicular growth of the hexagonal crystals. Also, note small dendrites on the deposit. On the other hand, a clear dendritic growth was detected in the deposits obtained at $-1.08 \mathrm{~V}$, Fig. $5 \mathrm{c}$. The morphological studies were consistent with the kinetically parameters detected from the potentiostatic study where an increase in the growth rate constant in the vertical direction to the substrate had higher values at bigger overpotentials applied.

a

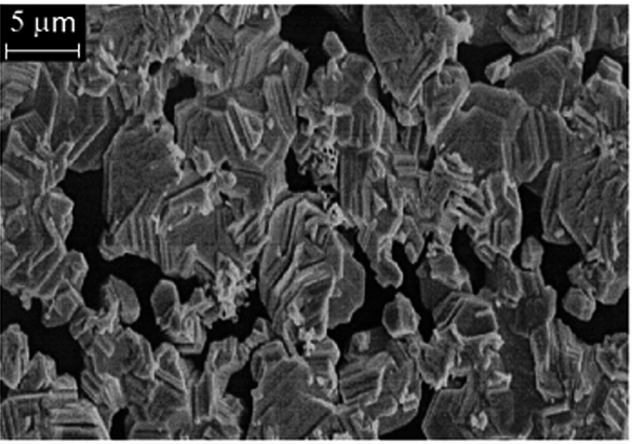

b

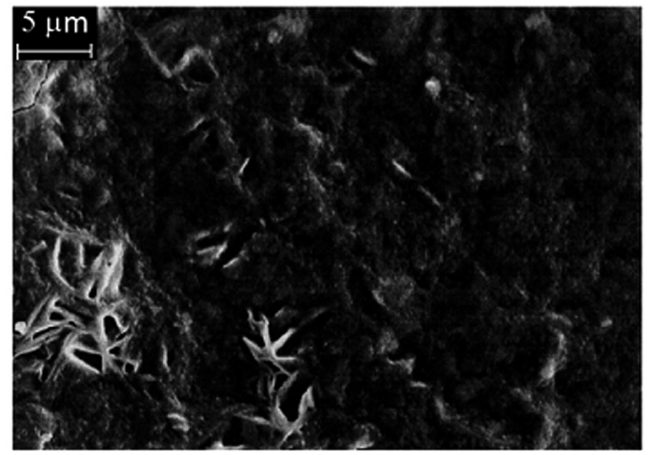

C

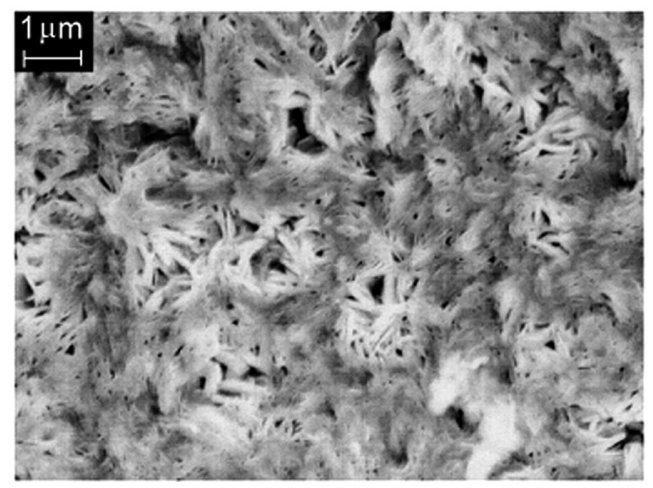

Fig. 5. SEM images of $\mathrm{Zn}$ electrodeposited under potentiostatic conditions at a) $-1.045 \mathrm{~V}(4480 \mathrm{X}), \mathrm{b})-1.065 \mathrm{~V}(4480 \mathrm{X})$ and c) -1.080 $\mathrm{V}(12250 \mathrm{X})$ from the $\mathrm{GCE} / 0.5 \mathrm{M} \mathrm{ZnCl}_{2}$ and $0.4 \mathrm{M} \mathrm{H}_{3} \mathrm{BO}_{3}(\mathrm{pH} 4.5$ ) system. 


\section{Conclusions}

We have studied $\mathrm{Zn}$ electrodeposition onto glassy carbon electrode from $0.5 \mathrm{M} \mathrm{ZnCl}_{2}, 25 \mathrm{~g} / \mathrm{H} \mathrm{H}_{3} \mathrm{BO}_{3}$ aqueous solution by using cyclic voltammetric and potentiostatic techniques. From the voltammetric study, it was possible to find that under our experimental conditions, the electrodeposition of zinc occurs under charge transfer control and it is quasi-reversible. The nucleation and growth parameters calculated, indicated that at lower potentials a perpendicular growth is favored suggesting a dendritic growth at bigger overpotentials. The Scanning Electron Microscopy images showed the formation of thin platelets of hexagonal crystals and dendrites, according to the predicted by the parameters obtained in the kinetic study.

\section{Experimental}

All experiments were carried out at room temperature $\left(25^{\circ} \mathrm{C}\right)$. A standard three-compartment electrochemical cell was used for the experiments. The cell was filled with a $0.5 \mathrm{M} \mathrm{ZnCl}_{2}$ and $0.4 \mathrm{M} \mathrm{H}_{3} \mathrm{BO}_{3}$ solution. A saturated calomel electrode (SCE) was used as reference electrode and a platinum wire as counter electrode. The working electrode was a disc of glassy carbon with a radius of $3 \mathrm{~mm}$. The exposed surface area of GCE was polished to a mirror finish with different grades of alumina down to $0.05 \mu \mathrm{m}$ and ultrasonically cleaned before the experiments. The electrochemical experiments were carried out in a PARC M-270 potentiostat connected to a personal computer to allow control of experiments and data acquisition. For morphology analyses a scanning electron microscope LEICA Model S420 was used.

\section{Acknowledgments}

We gratefully acknowledge financial support from CONACyT project APOY-COMPL-2008 No. 91261 and to the Universidad Autónoma del Estado de Hidalgo. We are also grateful to the reviewers of the manuscript for valuable suggestions.

\section{References}

1. Barcelo, G.; Sarret, M.; Muller, C.; Pregonas, J. Electrochim. Acta 1988, 43, 13-20.

2. Rajendran, S.; Bharanti, S.; Krishna, C. Plat. Surf. Finish. 1997, $84,53-57$.
3. Hosny, A. Y.; El-Rofei, M. E.; Ramadan, T. A.; El-Gafari, B. A. Met. Finish. 1995, 93, 55-59.

4. Bozzini, B.; Accardi, V. ; Cavalloti, P. L. ; Pavan, F. Met. Finish. 1999, 97, 33-33.

5. Trejo, G.; Ortega-Borges, R.; Meãs, Y. V.; Chainet, E.; Nguyen, B.; Ozil, P. J. Electrochem. Soc. 1998, 145, 4090-4097.

6. Singh, D. D. N.; Dey, M.; Singh, V. Corrosion 2002, 58, 971-980.

7. Sanchez-Cruz, M.; Alonso, F.; Palácios, J. M. J. Appl. Electrochem. 1993, 23, 364-370.

8. Yu, J.; Yang, H.; Ai, X., Chen, Y. Russ. J. Electrochem. 2002, 38, 321-325.

9. Baik, D. S.; Fray, D. J. J. Appl. Electrochem. 2001, 31, 11411147.

10. Deblauw, K.; Deboeck, A.; Bollen, J.; Timmermans, W. Proc. ICOTOM 12 Montreal, Quebec, Canada 1999, p. 1293-1295.

11. Ye, X.; Celis, J. P.; De Bonte, M.; Roos, J. R. J. Electrochem. Soc. 1994, 141, 2698-2708.

12. Park, H.; Szpunar, J. A. Proc. ICOTOM 12, Montreal, Quebec, Canada 1999, p. 1421-1424.

13. Tomov, I.; Cvetkova, C. H. R.; Velinov V. J. Appl. Electrochem. 1989, 19, 377-382.

14. Raeissi, K.; Saatchi, A.; Golozar, M. A. J. Appl. Electrochem. 2003, 33, 635-642.

15. Alvarez, A. E.; Salinas, D. R. J. Electroanal. Chem. 2004, 566, 393-400.

16. Torrent-Burgués, J.; Guaus, E. J. Appl. Electrochem. 2007, 37, 643-651.

17. Gomes, A.; Viana, A. S.; Da Silva Pereira, M. I. J. Electrochem. Soc. 2007, 154, D452-D461.

18. Vasilakopoulos, D.; Bouroushian, M.; Spyrellis, N. Electrochim. Acta 2009, 54, 2509-2514.

19. Sillen, L. G.; Stability Constants of Metal-Ion Complexes. Sect. 1: Inorganic Ligands, London: Metcalfe Copper Ltd, 1964.

20. Elpelboin, I.; Ksouri, M.; Wiart, R. J. Electrochem Soc. 1975, $112,1206-1214$

21. Elpelboin, I.; Ksouri, M.; Wiart, R. Faraday Disc. Chem Soc. 1978, 12, 115-120.

22. Taguchi, A. S.; Bento, F. R.; Mascaro, L. H. J. Braz. Chem. Soc. 2008, 19, 727-733.

23. Ibrahim, M. A. M. J. Chem. Technol. Biotechnol. 2000, 75, 745755

24. Aleksandar, R.; Despic, P. M. G. Electrochim. Acta 1982, 27 , 1539-1549.

25. Greef, R.; Peat, R.; Peter, L. M.; Pletcher, D.; Robinson, J. Instrumental Methods in Electrochemistry, Ellis Horwood, Chichester, 1985, Ch. 9.

26. Berzins, T.; Delahay, P. J. Am. Chem. Soc. 1953, 75, 555-559.

27. Delahay, P. New Instrumental Methods in Electrochemistry, Interscience, New York, 1954, p. 122-125.

28. Bard, A. J.; Faulkner, L. R., Electrochemical Methods, Fundamentals and Applications, John Wiley \&Sons, Inc., 2000.

29. Matsuda, H.; Ayabe, Y. Z. Elektrochem. 1955, 59, 494-503

30. Aoki, K.; Osteryoung, J. J. Electroanal. Chem. 1980, 110, 19-35.

31. Abyaneh, M. A.; Fleischmann, M. J. Electroanal. Chem. 1981, 119, 187-208.

32. Milchev, A.; Electrocrystallization: Fundamentals of nucleation and growth, Kluwer Academic Publishers, 2002, Chapter. 2.2.3. 